\title{
The Use of English Dictions in Promoting Various Cultural Heritage of The Indonesian Archipelago during The Covid-19 Pandemic
}

\author{
Jumino $^{* *}$, Joko Wasisto ${ }^{1 *}$, and Ika Krismayani ${ }^{{ }^{*}}$ \\ ${ }^{1}$ Library Science Department, Faculty of Humanities, Universitas Diponegoro, Jalan Prof.Soedarto \\ Tembalang, Semarang Indonesia
}

\begin{abstract}
During the current Covid-19 pandemic, foreign people can't visit Indonesia to enjoy the beauty of the cultural heritage of the Indonesian archipelago. The internet has become an effective medium for bridging, as the medium is interactive using multimedia, combining text, image, audio, and video formats. For this reason, the purpose of this study is to determine the effect of the use of English in informing cultural heritage of the Indonesian archipelago to the outside community using the internet. This research uses qualitative methods with data collection using literature study and documentation. The results showed that the use of English in disseminating information on the cultural heritage of the Indonesian archipelago is just descriptive only. Thus, it is necessary to use persuasive dictions to attract foreign tourists to visit Indonesia after the Covid-19 pandemic has vanished.
\end{abstract}

\section{Introduction}

Indonesia is a country that has a variety of very specific and interesting types of Indonesian culture, from Sabang to Merauke. The cultural heritage is in the form of physical and non-physical objects. Physical cultural heritage is in the forms of various places of worship, such as temples, mosques, churches, temples, and pagodas, the remains of the tombs of famous kings in ancient times, and the spreaders of Islam in the Indonesian archipelago [1]. The non-physical heritage is in the forms of traditional arts, such as religious rituals, traditional dance performances, puppets, and ketoprak [2]. These cultural relics are an attraction for domestic tourists and foreign tourists when they make tourism visits. For that, there must be a good promotion, not only aimed at the Indonesian people but also for the world community [3].

The COVID-19 pandemic, which has been going on for almost two years and has no signs of ending, has destroyed activities in various business fields, including the tourism sector [4]. This is due to the prohibition of visiting tourism attractions, or at least there are restrictions on visits to and from these tourism attractions [5]. Conditions like this at least can still promote the cultural heritage of the Indonesian archipelago through the internet.

\footnotetext{
${ }^{*}$ Corresponding author: jumino@live.undip.ac.id
} 


\section{Literature Review}

\subsection{Language and Tourism}

According to Dann [6], the relationship between language and tourism can be viewed from four theoretical approaches. These are authenticity, oddity, play, and conflict. According to him, tourism attraction is a sign that represents (marking) something (sight) to someone (tourist).

\subsection{Promotion and Marketing}

According to Kotler and Armstrong [7], promotion means activities that communicate product advantages and persuade customers. According to Tjiptono [8], in essence, promotion is a form of marketing communication. What is meant by marketing communication is marketing activities that seek to disseminate information, influence/persuade, and the target market of the company and its products to be willing to accept, buy, and be loyal to the products offered by the company concerned [9].

\subsection{Tourism Promotion Language}

Promotional language cannot be separated from the use of diction, construction of phrases, clauses, sentences, the use of rhetorical staging, patterned expressions, and discourse markers [10], in addition to other sources of meaning such as pictures, illustrations, logos, maps, etc. All the components mentioned above must be used as a driving force so that readers or potential tourists are interested, persuaded, and motivated to visit the tourist destinations offered.

Seaton \& Bennett [11] mention that promotion in tourism has the following specific objectives. "Effective promotion starts, like any other marketing activity, from analysis and clear formulation of strategic objectives. These involve identification of the target audiences to be reached (1); identification of the communication goals to be achieved with each (2); formulation of messages designed to achieve the goals (3); choice of media for delivering the messages effectively to the designated audiences (4); allocation of a budget to achieve the production and delivery of the messages (5); and evaluation mechanism in terms of sales (6).

Online tourism promotion has several advantages because it proves beneficial. The online promotion utilizes all sources of meaning in the form of language, images, music illustrations, colours, fonts choices, layouts, and logos [12]. With the increasing number of internet users in Indonesia, the choice of promoting online has become a mainstay for business people because it is cost-effective compared to promoting through electronic media such as television and can be accessed by people all over the world [13].

\subsection{English Dictions in Promotion}

Diction is the selection of the right words to express a meaning in conveying an idea. In promotional language, diction certainly leads to word choices that contain persuasive elements [14]. With a little provocative, it hoped that society would be interested and triggered to take action on their interests, such as visiting the places mentioned in the information. The information deals with the cultural heritage of the Indonesian archipelago informed through the website in English [15]. The right dictions must lead to the vocabularies of the information presented. In this study, the dictions discussed are the field of tourism information, 


\section{Research Method}

Research method used in this research is qualitative method through document study to collect data from websites containing information about various cultural heritage of the Indonesian Archipelago. To get data, the writer searches websites containing promotion of cultural heritage of the Indonesian Archipelago that use English as a means of informing the heritage, Then, searching the informative words to promote the heritage is done. The data, based on the results of the searches, are then analysed qualitatively [16]. The qualitative method used in this research is to get deep analysis.

\section{Results and Discussion}

During the Covid-19 pandemic, various business sectors in Indonesia experienced a drastic decline [3]. This was due to the prohibition on visiting existing tourism attractions. At least there were restrictions on visits and places where conditions like this required the tourism sector to be able to display the tourism attractions, they provide so that they can be visited virtually [5]. In this study, this study focuses on efforts to promote cultural tourism of the Indonesian archipelago through the internet to people abroad or around the world so that they become interested in knowing the various cultural heritage of the Indonesian archipelago in Indonesia. It is hoped that later they will visit it when the Covid-19 pandemic has been overcome.

For this research, the documentation method is used, which means that in Indonesia, especially with regard to the cultural heritage of the Indonesian archipelago, on www.indonesia-tourism.com. The site contains information on the various cultural heritage of the Indonesian archipelago, from Sabang to Merauke. Based on the use of English to convey information regarding the existing cultural heritage of the Indonesian archipelago, it will be analysed about the language used, whether it is just information or there is an element of promotion in conveying information. The following are ten links from www.indonesia-tourism.com dealing with the cultural heritage of the Indonesian archipelago to discuss.

\subsection{Arjuna Temple}

The first source cited is from Arjuna Temple, A Relic of Hindu in the Ancient Mataram Kingdom (https://www.indonesia-tourism.com/blog/arjuna-temple-a-relic-of-hindu-in-theancient-mataram-kingdom/)

"Arjuna Temple complex is the most photographed and visited of the surviving temples on the Dieng Plateau. Situated just a few hundred meters from the homestays in Dieng village, they are an obvious first stop on a tour of the sights in the area. ....." (Arjuna Temple, A Relic of Hindu in the Ancient Mataram Kingdom)

To promote the Indonesian cultural heritage of Arjuna Temple, some dictions are used, such as 'complex', 'homestays', 'glimpse', 'magnificent setting', and 'compelling attraction'. These indicate that Arjuna Temple is worth a visit by tourists because the temple is located in a very beautiful highland and is also surrounded by other temples. Foreign tourists can enjoy the atmosphere like in a cold country, even though it is in the tropics. Also, the temple is surrounded by beautiful panoramas and some very interesting craters. 


\subsection{Borobudur Temple}

The second source cited is from Borobudur Temple, One of Indonesia's Wonder Site, Magelang - Central Java (https://www.indonesia-tourism.com/blog/borobudur-temple-oneof-indonesias-wonder-site-magelang-central-java/)

"Borobudur Temple is one of World Seven Wonder that located in Magelang, Central Java. At early begin, this magnificent temple was built by using, more less, 55,000

$\mathrm{m} 3$ of stones. ....." (Borobudur Temple, One of Indonesia's Wonder Sites, Magelang)

To promote the Indonesian cultural heritage of Borobudur, some dictions are used, such as 'World Seven Wonders', 'magnificent temple', and 'limelight'. These indicate that Borobudur Temple must be visited by foreign tourists because it is a very large temple and is included in the UNESCO world site group. Besides being able to enjoy the greatness and beauty of the temple, foreign tourists can enjoy several tourist arenas around it. Also, its very strategic location allows the temple to be visited from various cities in Central Java and Yogyakarta. Especially now that there is Kulon Progo international airport, which is only a few tens of kilometers from Borobudur temple.

\subsection{Enchanted Semarang}

The third source cited is from Enchanted Semarang (https://www.indonesiatourism.com/blog/enchanted-semarang/)

"There are a lot of interesting places that worth to be visited in Semarang, regarding the historical background and, nature tourism or culinary places. For instance, there is an ancient church of GPIB Immanuel or most people recognize as Gereja Blendhuk or the church that having convex dome above the roof. ...." (From Enchanted Semarang)

To promote the Indonesian cultural heritage of Enchanted Semarang, some dictions are used, such as 'ancient church', and 'ancient buildings in Kota Lama'. These indicate that the city of Semarang should be visited by foreign tourists, as this city has a unique culture, namely the old culture in the form of buildings from the Dutch colonial.

\subsection{Labuhan Keraton Ngayogyakarta}

The fourth source cited is from Labuhan Keraton Ngayogyakarta (https://www.indonesiatourism.com/blog/labuhan-keraton-ngayogyakarta/)

"Labuhan Keraton or the Royal Offerings of Yogyakarta is usually performed on the 30th of Rajab, so it will probably be hold on Thursday, 27 April 2017, at 07.00 am at the "Pendhapa" (Javanese Mansion) of Kretek Subdistrict Office. ...." (Labuhan Keraton Ngayogyakarta)

To promote the Indonesian cultural heritage of Labuhan Keraton Ngayogyakarta, some dictions are used, such as 'Rajab', 'Pendhapa', 'ancak', and 'cepuri'. These indicate that The Labuhan Keraton Yogyakarta event is important to be watched by foreign tourists because this ceremony is very traditional and sacred related to the larung ritual. In this ritual, foreign tourists can see various traditional tools typical of Yogyakarta palace used in the ceremony. 


\subsection{MACAN Museum}

The fifth source cited is from MACAN Museum, Attractive Vacation Spot in Jakarta (https://www.indonesia-tourism.com/blog/macan-museum-attractive-vacation-spot-injakarta/)

"Jakarta City always becomes the center of tourism, especially for foreigners who spend a vacation in Indonesia. It is the capital city of the nation, after all. That means Jakarta becomes a perfect checkpoint before visiting other regions. " (MACAN Museum, Attractive Vacation Spot in Jakarta)

To promote the Indonesian cultural heritage of MACAN Museum, some dictions are used, such as 'perfect checkpoint', 'attractive vacation spots', and 'see numerous art collection'. These indicate that the tiger museum is worth a visit when foreign tourists visit Jakarta because they can see various types of cultural heritage stored in the museum.

\subsection{Pekalongan}

The sixth source cited is from Pekalongan - Central Java (https://www.indonesiatourism.com/blog/pekalongan-central-java/)

"Pekalongan has long been known as batik city, and one of the batik production centers are located in District Buaran and Wiradesa. ....." (Pekalongan - Central Java)

To promote the Indonesian cultural heritage of Pekalongan, some dictions are used, such as 'batik city', 'manufacturers', and 'cloth palekat'. These indicate that Pekalongan is a city that needs to be visited because it is the largest batik city in Indonesia, a wide variety of batik is produced in the city and is a very good souvenir when foreign tourists visit Indonesia by going directly to Pekalongan, the tourists will get a cheap price compared to when buying in galleries.

\subsection{Penglipuran Village}

The seventh source cited is from Penglipuran Village As The Pure Culture Village in Bali (https://www.indonesia-tourism.com/blog/penglipuran-village-as-the-pure-culture-villagein-bali/)

"Penglipuran can indeed be an example, how tourist villages are built. His achievements also lined up. In 2016 Penglipuran was chosen as the 3rd cleanest village in the world according to the international magazine Boombastic. ..... Penglipuran Village as The Pure Culture Village in Bali)

To promote the Indonesian cultural heritage of Penglipuran Village as The Pure Culture Village in Bali, some dictions are used, such as 'tourist villages', 'cleanest village', 'cultural preservation', and 'Pure Culture Village'. These indicate that Pelipuran village should be visited by foreign tourists because it has advantages such as being the cleanest village and still preserving cultural customs, and taking good care of the environment.

\subsection{Ratu Boko Temple}

The eighth source cited is from Ratu Boko Temple, Yogyakarta (https://www.indonesiatourism.com/blog/ratu-boko-temple-yogyakarta/) 
"Ratu Boko temple is located on a plateau, about three kilometres south of Lara Jonggrang Prambanan temple complex in Yogyakarta Central Java, Indonesia. ...." (Ratu Boko Temple, Yogyakarta)

To promote the Indonesian cultural heritage of Ratu Boko Temple, some dictions are used, such as 'the largest and most often photographed structures', 'Ratu Boko', and 'religious in nature'. These indicate that Boko Temple is a historical temple used for religious rituals. The name of this temple is associated with the existence of Ratu Boko who has a sister named Roro Jonggrang, the popular Javanese legend.

\subsection{The Caping Dance}

The ninth source cited is from The Caping Dance (https://www.indonesiatourism.com/blog/the-caping-dance/)

"Caping Ngancak dance is one of traditional dances in Lamongan regency. The dance is describes about farmers in their rice field showing the process from grow the rice until they get harvest. Like farmers, the dancers also wearing 'Caping', which is a special hat that only wore by farmer in Indonesia. ....." (Caping Ngancak Dance)

To promote the Indonesian cultural heritage of the Caping Ngancak Dance, some dictions are used, such as 'traditional dances', 'harvest', 'caping', and 'village costumes'. These indicate that caping dance is a dance performed by the community as an expression of gratitude to the Creator for the harvest they get. Caping is a traditional hat as a head covering by farmers when they are working in the fields or in the fields.

\subsection{Yapong Dance}

The tenth source cited is from Yapong Dance, One of Betawi Folk Dance (https://www.indonesia-tourism.com/blog/yapong-dance-one-of-betawi-folk-dance/)

"Yapong dance is typical of traditional happy dance that having delicate and kind of. The term of Yapong was taken from the song that follows the dance which sounds 'ya ya ya' and the sound of the music that heard like 'pong pong pong'. ..." (Yapong Dance, One of Betawi Folk Dance)

To promote the Indonesian cultural heritage of Yapong Dance, some dictions are used, such as 'traditional happy dance', 'erotic moves', 'ya ya ya', and 'pong pong pong'. These indicate that this type of dance depicts an erotic traditional dance with interesting sounds during the dance.

\section{Conclusion}

The use of English dictions for promoting the various cultural heritage of the Indonesian archipelago has been used by the same website. One of them is www.indonesia-tourism.com. This website has uploaded some information about the cultural heritage of the Indonesian archipelago. However, the information given is still descriptive but not persuasive. There are no dictions dealing with tourism promotion of heritage. On the other hand, persuasive dictions must be used to make the world community not only understand the cultural heritage of the Indonesian archipelago, but also will visit Indonesia after the Covid-19 pandemic has been overcome.

The author would like to thank Faculty of Humanities, Diponegoro University for funding this research and Prof. Dr. Tri Retnaningsih Soeprobowati, for facilitating this article to publish. The author would also like to thank all those who have contributed to the implementation of this research. 


\section{References}

1. A. Lukman, Community-based management of the USAT Liberty, Bali, Indonesia: Pathways to sustainable cultural heritage tourism, J. Cult. Herit. Manag. Sustain. Dev., 10(3), 217-231 (2020)

2. M. Nagaoka, Buffering borobudur for socio-economic development an approach away from european values-based heritage management, J. Cult. Herit. Manag. Sustain. Dev., 5(2), 130-150 (2015)

3. F. Kurnianingsih, I. Zulkarnain, and M. Mahadiansar, How Social Economic Impact Tourism Development in Pandemic COVID-19? Study of Bintan Regency, Indonesia, (2021)

4. S. Susilawati, R. Falefi, A. Purwoko, Impact of COVID-19's Pandemic on the Economy of Indonesia, Budapest Int. Res. Critics Inst. Humanit. Soc. Sci., 3(2), 1147-1156 (2020)

5. M. E. Atmojo, H. D. Fridayani, An Assessment of Covid-19 Pandemic Impact on Indonesian Tourism Sector, J. Gov. Public Policy, 8(1), 1-9 (2021)

6. G. Dann, The Language of Tourism: A sociolinguistic perspective. (CAB International Wallingford, 1996)

7. P. dan G. A. Kotler, Ed., . Principles of Marketing, (Pearson New York, 2010)

8. F. Tjiptono, Ed., Strategi Pemasaran. Edisi ,. (Andi Yogyakarta, 2008)

9. A. Syahrin, Health Protocol Certification for tourism business due to Covid-19 outbreaks in Bali, 5(1), 67-80 (2021)

10. Language for specific purposes, Annu. Rev. Appl. Linguist., (2000)

11. Seaton \& Bennett, Marketing tourism products: concepts, issues, cases, (International Thomson Business Press London, 1996)

12. K. L. O’Hallorn, Multimodal Discourse Analysis: Systemic Functional Perspectives. (Continuum London, 2004)

13. A. Wibowo, D. Kristina, Efektivitas penggunaan bahsa inggris dalam media promosi pariwisata Solo Raya menuju pembangunan sistem online tourism promotion, Cakra Wisata, 19, 12-22 (2018)

14. Writing center modules diction \& style menlo college fall 2011, (2011)

15. E. Steelyana, Batik, A Beautiful Cultural Heritage that Preserve Culture and Supporteconomic Development in Indonesia, Binus Bus. Rev., 3(1), 116 (2012)

16. I. Ismail, E. Elihami, Pelatihan penyusunan artikel publikasi ilmiah bagi mahasiswa perguruan tinggi STKIP Muhammadiyah Enrekang, Maspul J. Community Empower., 1(1), 12-20 (2019) 